\title{
Immunochemical detection of dissolved proteins and their source bacteria in marine environments
}

\author{
Satoru Suzuki ${ }^{1, *}$, Kazuhiro Kogure ${ }^{2}$, Eiichiro Tanoue ${ }^{3, * *}$ \\ ${ }^{1}$ Department of Aquaculture, Kochi University, Nankoku, Kochi 783, Japan \\ ${ }^{2}$ Ocean Research Institute, University of Tokyo, Minamidai, Nakano, Tokyo 164, Japan \\ ${ }^{3}$ Geochemical Research Department, Meteorological Research Institute, Tsukuba 305, Japan
}

\begin{abstract}
In order to expand upon the discovery that specific proteins survive in seawater as dissolved protein and that the origin of these proteins is bacterial porin, we surveyed marine environments and cultured bacteria for the presence of homologues of 2 kinds of bacterial porins. Antisera against the $\mathrm{N}$-terminus of the OprP porin of Pseudomonas aeruginosa and against the whole molecule of the Omp35La porin of Listonella (Vibrio) anguillarum were prepared and used as probes in Western blot analysis. In all samples collected in the subarctic and subtropical Pacific Ocean and the Antarctic Ocean, proteins reactive to the antisera were detected. The molecular masses of OprP and Omp35La are 48 and 33 to $37 \mathrm{kDa}$ respectively; detected proteins in seawater samples were generally also of similar molecular mass. However, dissolved proteins as well as outer membrane proteins from cultured bacteria with different molecular masses were detected using the antisera. This indicates that dissolved proteins and bacterial outer membrane proteins distinct from OprP and Omp35La contain similar antigenic structures to OprP and Omp35La. Fluorescent-antibody staining revealed that bacterial cells that were stainable with antisera were present in natural bacterial assemblages throughout the entire water column. Present observations strongly suggest that bacterial porins are a major source of dissolved proteins.
\end{abstract}

KEY WORDS: Dissolved protein - Bacteria $\cdot$ Porin

\section{INTRODUCTION}

Dissolved organic matter (DOM) in seawater is an important pool of organic matter in the global carbon cycle (e.g. Hedges 1987). Although the majority of DOM is marine in origin (e.g. Lee \& Wakeham 1989), DOM is thought to be a complex mixture of diagenetically altered organic matter (e.g. Cauwet 1978). DOM is perhaps the most poorly characterized organic pool on the earth.

Research on microbial food-web processes (e.g Pomeroy 1974, Azam et al. 1983) has revealed that $50 \%$ of organic matter (Ducklow \& Carlson 1992) generated by primary production is transferred to

-E-mail: ssuzuki@cc.kochi-u.ac.jp

- Present address: Institute for Hydrospheric-Atmospheric Sciences, Nagoya University, Chigusa-ku, Nagoya 464-01, Japan
DOM and then utilized by heterotrophic bacteria. The bulk chemical analyses in the 1990s also demonstrated that polysaccharides and combined amino acids comprise substantial portions of DOM (Keil \& Kirchman 1991, Benner et al. 1992, Pukulski \& Benner 1994) and that these organic constituents are more dynamic than previously believed (Amon \& Benner 1994, Guo et al. 1994, 1995). Since such chemical analyses were made by colorimetric bulk analyses, or by analyses at the monomer level after hydrolysis of macromolecules, it is difficult to deduce source macromolecules from monomer-level information. It is, therefore, hard to specify the source of detected biochemical compounds in DOM and the relationships between organic constituents in organisms and organic constituents in DOM are not well documented.

Recently, Tanoue and his co-workers have discovered that a limited number of dissolved protein species account for the majority of the dissolved protein com- 
ponents in seawater collected from the northern North Pacific, through the subtropical and equatorial Pacific and the Indian Ocean, to the Antarctic Ocean (Tanoue 1995, Tanoue et al. 1995, 1996).

The N-terminal amino acid sequencing of dissolved proteins revealed that a $48 \mathrm{kDa}$ protein, one of the major components in dissolved proteins, had the same $\mathrm{N}$ terminal amino acid sequence as the outer membrane protein OprP of Pseudomonas aeruginosa, which is a porin channel specifically expressed under phosphate deficient conditions (Hancock et al. 1982). The evidence strongly suggests that specific biomolecules can escape degradation and be stable in seawater as dissolved protein. Proteins other than the $48 \mathrm{kDa}$ protein, however, did not show any homology with known polypeptides cited in the database (Japan International Protein Information Database). The database of porins for comparison is still very limited. These findings led us to hypothesize that some other dissolved proteins might contain bacterial porins other than those of $P$. aeruginosa. Pseudomonadaceae belongs to the $\gamma$ subclass of Proteobacteria. Although detailed study on this particular group seems to be scarce, the $\gamma$ subclass is usually found as one of the major constituents of marine microbial populations (Giovannoni et al. 1990, Schmidt et al. 1991). P. aeruginosa is thought to be distributed in soil-and freshwater environments, but its occurrence in the sea is questionable. Therefore, $P$. aeruginosa is not necessary the sole candidate for the production of the $48 \mathrm{kDa}$ protein.

In this study, we surveyed the presence of 2 bacterial porin homologues in seawater columns to test the hypothesis that bacterial porins are major sources of dissolved proteins. OprP and Listonella (Vibrio) anguillarum Omp35La porins were the target proteins in this study. The survey was performed by Western blotting probing with antisera against the N-terminal 14 -mer of OprP and the whole molecule of Omp35La. L. anguillarum is a well-known fish pathogenic marine bacterium (Holt et al. 1994). The biochemical and serological properties of Omp35La, one of the constitutive porins of $L$. anguillarum, have been relatively well characterized (Suzuki et al. 1993, 1996, Simon et al. 1996).

\section{MATERIALS AND METHODS}

Sampling of seawater and analysis of disssolved protein. Samples analyzed in this study were collected at Stns $\mathrm{A}\left(45^{\circ} 10.3^{\prime} \mathrm{N}, 165^{\circ} 34.4^{\prime} \mathrm{E}_{i}\right.$ subarctic Pacific) and $\mathrm{B}\left(24^{\circ} 35.0^{\prime} \mathrm{N}, 170^{\circ} 0.1^{\prime} \mathrm{E}\right.$; subtropic Pacific) from 18 October to 11 November 1993 on a cruise of the RV 'Hakuho-maru' (cruise KH-93-4). Samples of seawater were collected with a diaphragm-type air-driven pump at Stn A (at depths of 5,50 and $200 \mathrm{~m}$ ) and with the Niskin-type bottles mounted on a CTDO-rosette multiple sampler at Stn B (at depths of 75, 100, 200, 500, 1000 and $2000 \mathrm{~m}$ ). Each sample (ca 20 l) was passed through a GF/F glass-fiber filter (Whatman) immediately after sampling. Another set of samples named JARE 34 was obtained from 20 November 1992 to 19 March 1993 during the cruise of the 34th Japan Antarctic Research Expedition (JARE 34). Seawater pumped from below the ship ( $-5 \mathrm{~m}$ below the surface) was continuously passed through a GF/F filter and was collected twice per day. Individual samples (ca 5 l) of filtrates were pooled to yield 1 composite sample. Samples were named 34-14 (sample volume: 17.4 l) and 34-11 (27.8 l) and were composed of 3 and 5 individual samples collected from $38^{\circ} 10^{\prime} \mathrm{S}, 151^{\circ} 15^{\prime} \mathrm{E}$, to $35^{\circ} 38^{\prime} \mathrm{S}$, $151^{\circ} 34^{\prime} \mathrm{E}$ and $63^{\circ} 00^{\prime} \mathrm{S}, 127^{\circ} 27^{\prime} \mathrm{E}$ to $64^{\circ} 57^{\prime} \mathrm{S}, 148^{\circ}$ $18^{\prime} \mathrm{E}$, respectively.

Dissolved proteins in the filtrate were concentrated using tangential flow ultrafiltration systems (Pelicon and Minitan; Millipore) with a filter with nominal molecular mass cut-off of $10 \mathrm{kDa}$ (the filter material was low-protein-binding regenerated cellulose) after addition of sodium dodecylsulfate (SDS; $0.01 \%$ in final conc.). The concentrate was desalted with $35 \mathrm{mM}$ ammonium bicarbonate buffer ( $\mathrm{pH} 7.8$ ) that contained $0.01 \%$ SDS. The dissolved protein in the concentrate was further concentrated and purified with trichloroacetic acid (TCA; 5\% in final conc.). The TCAinsoluble fraction was obtained by centrifugation at $14000 \times g$ for $30 \mathrm{~min}$ at $4^{\circ} \mathrm{C}$ and was then subjected to sequential washing with TCA (5\%), ethanol (100\%), and diethyl ether (100\%). The final pellet on the bottom of the centrifuge tube was air-dried.

Each dried pellet of the dissolved protein samples was redissolved in a sample buffer solution of $62.5 \mathrm{mM}$ Tris- $\mathrm{HCl}(\mathrm{pH} 6.8), \operatorname{SDS}(2 \%, \mathrm{w} / \mathrm{v}), 2$-mercaptoethanol $(5 \%, v / v)$ and glycerol $(10 \%, w / v)$ and heated to $100^{\circ} \mathrm{C}$ and maintained at this temperature for $3 \mathrm{~min}$. This was then analyzed by SDS-polyacrylamide gel electrophoresis (SDS-PAGE) and subsequent Western blotting.

Detailed descriptions of SDS-PAGE of the dissolved protein samples have been reported by Tanoue (1995). Proteins were stained with Coomassie blue R-250. Western blotting was performed basically according to the method of Towbin et al. (1979) and Morita et al. (1996). Detection of the antibody reactive proteins was done by using an Immunostaining HRP-1000 kit (Konica).

Preparation of bacterial outer membrane proteins. Bacterial outer membrane proteins were purified from 10 strains of cultured bacteria, Pseudomonas aeruginosa, P. nautica, Deleya marina, Marinomonas communis, $M$. vaga, Alteromonas macleodii, A. haloplanktis, Vibrio parahaemolyticus, Photobacterium phosphoreum and 
Aeromonas caviae. Purification was performed using the method of Kragelund \& Nybroe (1994).

Antisera. Two antisera were used as probes for the Western blotting analysis. Antiserum against the $\mathrm{N}$ terminal 14 -mer of a $48 \mathrm{kDa}$ protein ( $\alpha$-48DP N-14) was prepared as follows: (1) N-terminal 14-mer GTVTTDGADIVIKT was chemically synthesized. (2) Cystein was added to the $\mathrm{N}$-terminus of this oligomer in order to cause a reaction with the carrier protein with the disulfide bond. (3) This 14-mer was then conjugated to maleimide activated bovine serum albumin (BSA; Pierce); non-reacted oligomer was removed by dialysis against phosphate buffered saline. (4) Of the conjugated product, $2.7 \mathrm{mg}$ was mixed with Freund's complete adjuvant and injected into a male New Zealand white rabbit. (5) After 2 wk, a booster injection of the same amount of the conjugated product was given to the rabbit. Antiserum displaying specificity against the $\mathrm{N}$-terminus of the $48 \mathrm{kDa}$ protein as judged using Western blot analysis was from rabbits 2 to $3 \mathrm{wk}$ post boosting. From this antiserum, anti-BSA antibody was removed by an immunoprecipitation (Harlow \& Lane 1988) by mixing with 1\% BSA. This antiserum could detect the $48 \mathrm{kDa}$ protein as a single band with $1: 100$ to $1: 500$ dilution in Western blotting when cell homogenate of Pseudomonas aeruginosa was employed in the analysis. This indicates that the antiserum is specifically reactive to OprP.

Antiserum against Omp35La of Listonella (Vibrio) anguillarum ( $\alpha$-Omp35La) was prepared as has been described previously (Suzuki et al. 1993). We prepared antisera against $\mathrm{mp} 35 \mathrm{La}$ of $L$. anguillarum serotypes $\mathrm{J}-\mathrm{O}-1,-2$ and -3 . Of these, the antiserum against Omp35La purified from a strain serotyped J-O-2 was used throughout this study because of its broad spectrum in reaction (Suzuki et al. 1996). This antiserum could detect Omp35La of L. anguillarum and similar porins of bacteria belonging to the genera Vibrio and Photobacterium (Suzuki et al. 1996) with 1:200 to 1:1000 dilution as a single band in Western blotting. This indicates that the antiserum was specific to Omp35La and related porins as has been reported in a previous paper (Suzuki et al. 1996).

Detection of $\alpha$-48DP N-14-reactive bacteria. For the detection of the $\alpha-48$ DP N-14-reactive bacteria in natural bacterial assemblages, samples of seawater were collected from January 30 to February 2, 1996 during the KT-96-2 cruise of RV 'Tansei-maru' off the coast of Japan. Samples collected at Stn 3 (34 42.073' N $137^{\circ} 06.993^{\prime} E_{i}$ middle part of Mikawa Bay), Stn 4 (34 $33.961^{\prime} \mathrm{N}, \quad 137^{\circ} 09.459^{\prime} \mathrm{E}_{i}$ outside of Mikawa Bay, $2 \mathrm{~km}$ from coastal line), Stn 7 (35 01.646' $\mathrm{N}$, $138^{\circ} 37.486^{\prime} \mathrm{E}_{;}$inside of Suruga Bay, $10 \mathrm{~km}$ from the innermost part) and $S t n 8\left(34^{\circ} 49.943^{\prime} \mathrm{N}, 138^{\circ} 25.973^{\prime} \mathrm{E}_{i}\right.$ middle part of Suruga Bay) were employed for the analysis. Samples were taken using ethanol-washed Niskin samplers, and seawater treatments were initiated within $1 \mathrm{~h}$ of being on board. For direct viable count (DVC) (Kogure et al. 1979), the seawater was incubated with $100 \mathrm{mg} \mathrm{l}^{-1}$ of yeast extract and $20 \mathrm{mg} \mathrm{l}^{-1}$ of nalidixic acid at $20^{\circ} \mathrm{C}$ for $6 \mathrm{~h}$ in the dark. Increase of nalidixic acid resistant bacteria is negligible in this incubation. Formalin-fixed samples ( $2 \%$ in final conc.) were stored in a cold room until use. Both total count and DVC were enumerated under epifluorescence microscopy (Olympus BH-2) with a $100 \mathrm{~W}$ mercury lamp after staining with DAPI (Porter \& Feig 1980).

Subsamples of the seawater incubated for DVC were used for indirect fluorescent-antibody (FA) staining with the $\alpha-48$ DP $N-14$. In general, in the natural bacterial population, cells were too small (less than $0.5 \mu \mathrm{m}$ ) to recognize their cellular shape. This was also true for coastal samples obtained by the 'Tansei-Maru' cruise. Without confirming cellular shape, it was difficult to differentiate positive reactions from the non-specific adsorption. This is why we used DVC samples for FA staining. Of the sample seawater 30 to $50 \mathrm{ml}$ portions were filtered through black Nuclepore filters (diameter $10 \mathrm{~mm}$, pore size $0.2 \mu \mathrm{m}$ ), and all staining procedures were performed on the filter as described by Xu et al. (1982). Instead of rhodamine isothiocyanate-BSA, however, partially hydrolyzed gelatin was applied to reduce the non-specific adsorption of the antiserum (Bohlool \& Schmidt 1968). Bacteria which displayed staining along their cellular margin were counted using a fluorescence microscope. At least 100 fields were counted in each filter. Preliminary experiments indicated that the sample size was too small to be employed for detection of $\alpha$-Omp35Lareactive bacteria.

\section{RESULTS}

\section{Detection of OprP and Omp35La homologues in the seawater column}

The dissolved protein fractions at Stns $A$ and $B$ and in the JARE 34 samples were analyzed by SDS-PAGE and by Western blotting. The results of these experiments are shown in Figs. 1, $2 \& 3$. The dissolved proteins at the subarctic Stn $A$ in the Pacific (Fig. 1), obtained from depths of 5,50 and $200 \mathrm{~m}$, gave banding patterns in SDS-PAGE indicating that specific proteins were present in these samples. In particular, bands migrating to approximately 34 and $48 \mathrm{kDa}$ were observed at all 3 depths (Fig. 1A). The proteins on these gels were transferred to nitrocellulose filters, and used in the Western blotting analysis. When the $\alpha-48$ DP N-14 was used as a probe, the $48 \mathrm{kDa}$ band was 
A

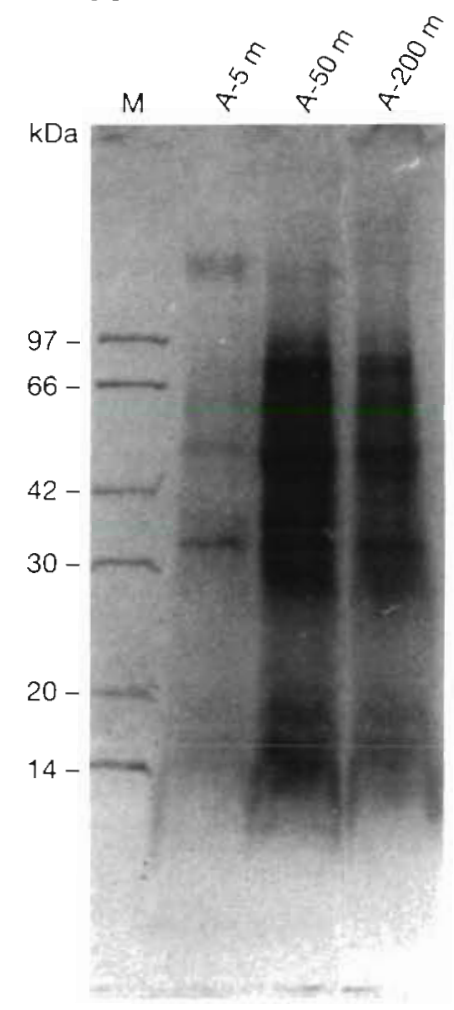

B

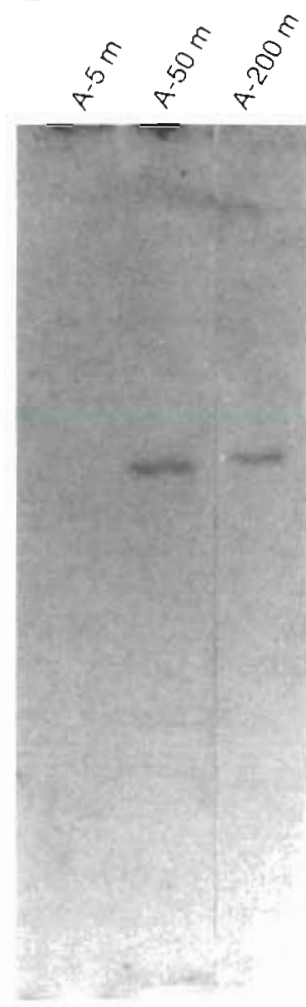

detected at depths of 50 and $200 \mathrm{~m}$ (Fig. 1B). A positive signal was not detected at a depth of $5 \mathrm{~m}_{i}$ however, this might have been because the amount of protein was not sufficient for this assay. On the other hand, $\alpha$ Omp35La reacted to $34 \mathrm{kDa}$ protein at depths of 50

\section{C}

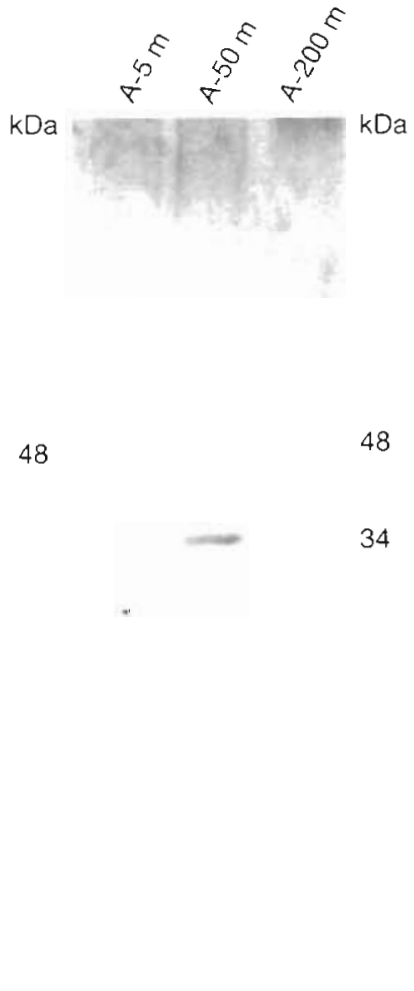

Fig 1. SDS-PAGE (A) and Western blotting $(B, C)$ of dissolved proteins obtained from subarctic Pacific Stn A. In Western blotting, $\alpha-48$ DP N-14 (B) and $\alpha$-Omp35La (C) were used as probes. Molecular weight is indicated as $\mathrm{kDa}$ for each lane, $M$ (size marker) and sampling depths are indicated

and $200 \mathrm{~m}$ (Fig. 1C). The $48 \mathrm{kDa}$ protein was also detected at all 3 depths, although the signal was weak.

Dissolved proteins obtained from subtropical Pacific Stn B (Fig. 2) did not possess the same banding pattern observed in the samples from Stn A. Several clear

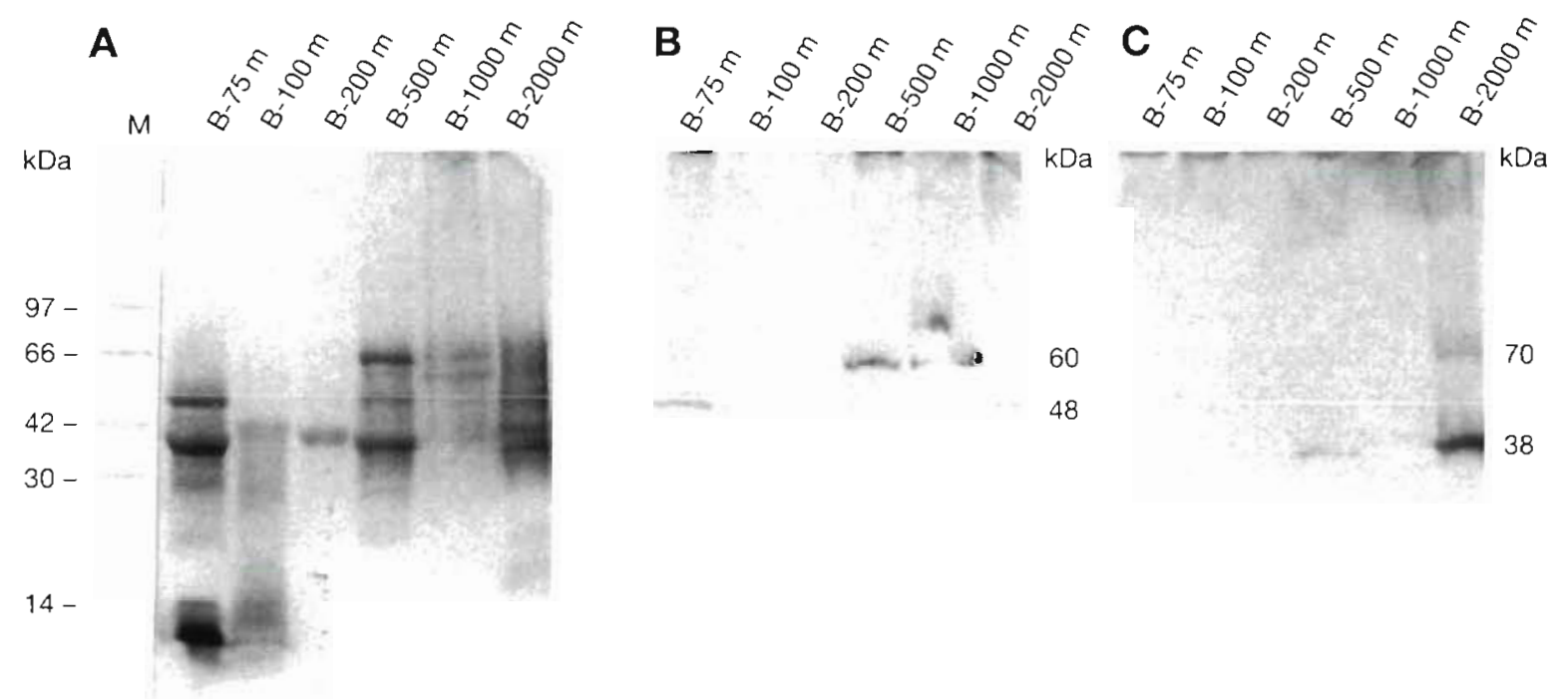

Fig. 2. SDS-PAGE (A) and Western blotting $(B, C)$ of dissolved proteins obtained from subtropical Pacific Stn $B$. Antisera used in Western blotting and presentation of results as in Fig. 1 
bands were observed in samples from all depths, although the banding patterns were different for each depth. Western blotting results obtained with $\alpha-48$ DP $\mathrm{N}-14$ showed immunoreactive bands at 48 and $60 \mathrm{kDa}$ (Fig. 2B), while those obtained with $\alpha$-Omp35La showed positive bands at 38 and $70 \mathrm{kDa}$ (Fig. 2C).

The surface samples in the Antarctic Ocean (JARE 34) showed several major bands along with a smeared SDS-PAGE pattern (Fig. 3A). Western blotting with $\alpha-48$ DP N-14 showed a single band with molecular mass of $48 \mathrm{kDa}$ (Fig 3B), and the $34 \mathrm{kDa}$ band was detected when $\alpha$-Omp35La was used (Fig. 3C). These results were similar to those obtained in samples from $\operatorname{Sin} A$.

\section{Antisera reactivity to bacterial outer membrane proteins}

Outer membrane proteins of cultured bacteria were purified and employed for Western blotting analysis. The bacterial outer membrane proteins derived from each species exhibited a specific profile in SDS-PAGE (Fig. 4A), and Western blotting using $\alpha-48$ DP N-14 (Fig. 4B) In the case of Pseudomonas aeruginosa (lane 1), a single band was detected at the anticipated position of molecular mass of $48 \mathrm{kDa}$ after Western blotting, thus verifying that the reaction of the $\alpha-48 \mathrm{DP}$ $\mathrm{N}-14$ is specific for OprP. However, $\alpha-48$ DP N-14 reacted to $18 \mathrm{kDa}$ outer membrane proteins prepared from Alteromonas macleodii (lane 6) and to $78 \mathrm{kDa}$ outer membrane proteins from Aeromonas caviae (lane 10). In the 7 other bacterial outer membrane samples, no positive bands were detected at all.

In the case of $\alpha$-Omp35La, the $33 \mathrm{kDa}$ band of Vibrio parahaemolyticus (lane 8 ) and the $40 \mathrm{kDa}$ band of Photobacterium phosphoreum (lane 9) were strongly positive (Fig. 4C). These results are consistent with previous results, i.e. that $\mathrm{Omp} 35 \mathrm{La}$ homologues in the genera Vibrio and Photobacterium are reactable with $\alpha$-Omp35La (Suzuki et al. 1996). Several positive bands were also detected in Pseudomonas aeruginosa (lane 1), Deleya marina (lane 3), Alteromonas macleodii (lane 6) and Aeromonas caviae (lane 10). It is probable that these reactive proteins have primary structures similar to Omp35La.

\section{Detection and vertical distribution of antiserum- reactive bacteria}

The Western blot results described above revealed that antisera $\alpha-48$ DP N-14 and $\alpha$-Omp35La reacted to dissolved proteins as well as outer membrane proteins
Fig. 3. SDS-PAGE (A) and Western blotting $(B, C)$ of dissolved proteins obtained from Antarctic Ocean surface by the 34th Japan Antarctic Research Expedition (JARE 34). Antisera used in Western blotting and presentation of results as in Fig. 1. Sample numbers at the top of the lanes are explained in the 'Materials and methods'

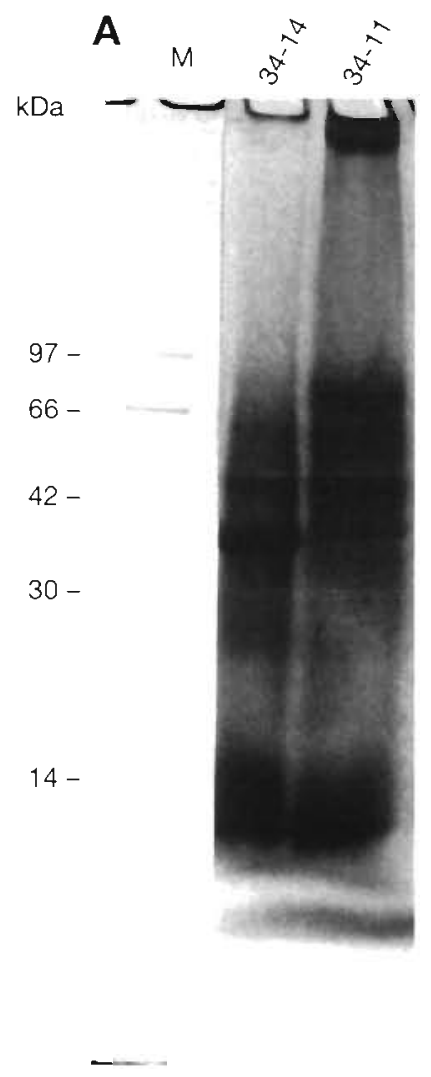

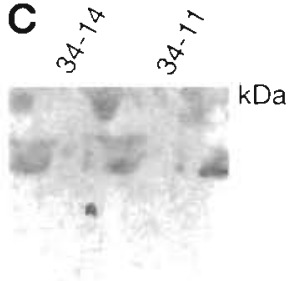

48

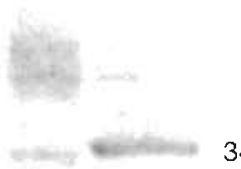


A

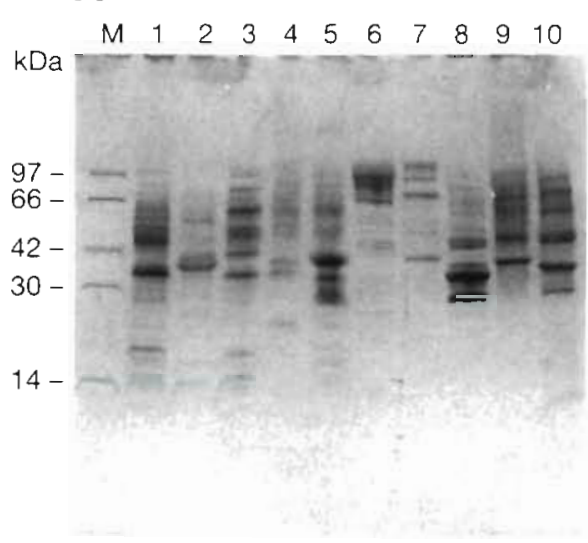

B

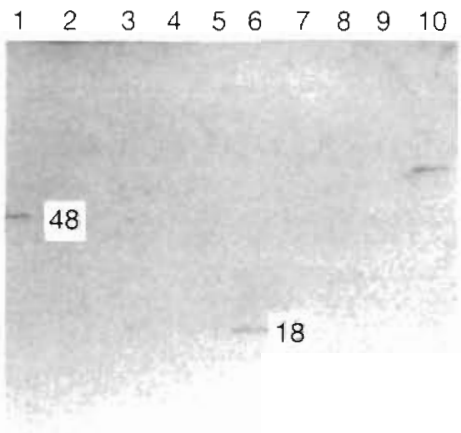

C

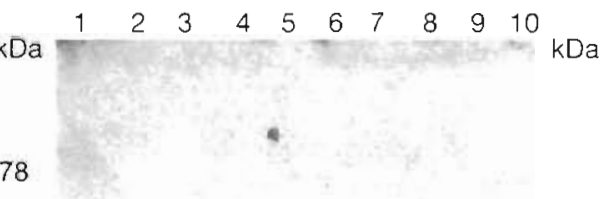

$-48$

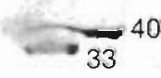

22

Fig. 4. SDS-PAGE $(A)$ and Western blotting $(B, C)$ of outer membrane proteins from 10 strains of cultured bacteria. Lanes 1, Pseudomonas aeruginosa; 2 , Pseudomonas nautica; 3 , Deleya marina; 4, Marinomonas communis; 5 , Marinomonas vaga; 6 , Alteromonas macleodii; 7. Alteromonas haloplanktis; 8, Vibrio parahaemolyticus; 9 , Photobacterium phosphreum; and 10, Aeromonas caviae. Molecular sizes of positive bands in Western blotting are indicated in $\mathrm{kDa}$ at the side of or in the panels

of bacteria. The reactivity of the antiserum $\alpha-48 \mathrm{DP}$ $\mathrm{N}-14$ to natural intact bacteria was also examined by immunostaining whole cells. Bacterial cells which reacted with the antiserum were detected in samples from all stations and depths examined as shown in Fig. 5. Their abundances were approximately 4 and 2 orders of magnitude lower than those of the total count and DVC, respectively. Vertical profiles of the $\alpha-48 D P$ $N$-14-reactive bacteria were approximately parallel to those of the DVC and the total count. However, detailed examination revealed the occurrence of small subsurface peaks at $75 \mathrm{~m}$ depth in the lower euphotic zone at Stns 7 and 8 .

\section{DISCUSSION}

It has been postulated that in the production of DOM, organic materials derived from marine organisms are transferred to the DOM pool, and a smail fraction of the degradated oligomeric products are transformed to humic matter. Therefore, a major portion of the DOM is refractory to degradation and consists of structurally unidentifiable molecules (e.g. Rashid 1985). However, the discovery of OprP homologues in seawater indicated the presence of another pathway for production of DOM whereby enzyme-resistant biopolymers selectively survive and accumulate in the ocean (Tanoue et al. 1995, 1996). Tanoue et al. $(1995,1996)$ also found several proteins other than the $48 \mathrm{kDa}$ protein OprP homo- logue. N-terminal amino acid sequences of the dissolved proteins other than the $48 \mathrm{kDa}$ protein did not provide any source-related information because no homologous sequences have been reported in any

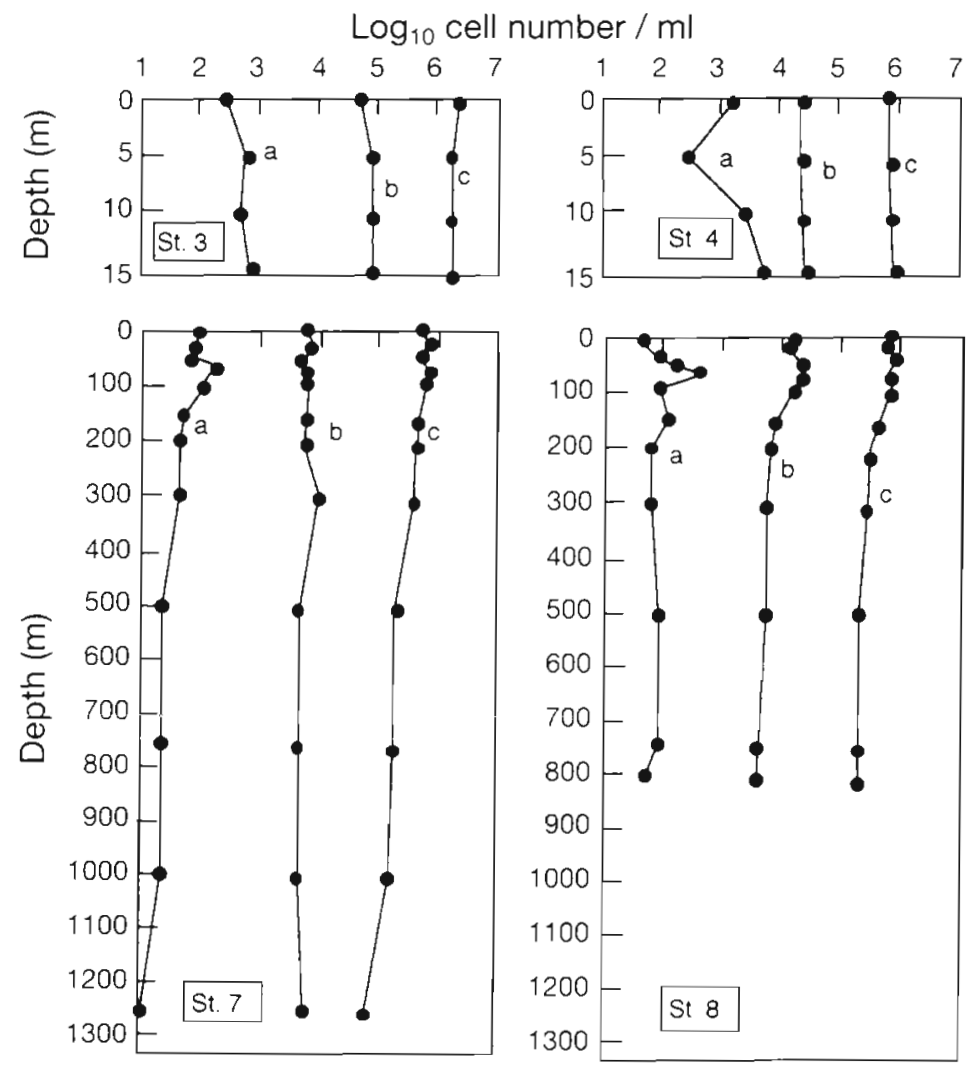

Fig. 5. Vertical distribution of $\alpha-48$ DP N-14-reactive cells at Stns $3,4,7$ and 8 (See 'Materials and methods'). Distributions of (a) a-48 DP N-14reactive cell numbers, (b) DVC (direct viable count) and (c) total count are shown 
sequence databases. Since few porins have been characterized at the molecular level and have appeared in databases, and since those porins characterized to date have similar physico-chemical properties, there is a possibility that dissolved proteins other than the $48 \mathrm{kDa}$ protein are also porins.

In order to test the hypothesis that bacterial porins are one of the types of specific biopolymers constituting dissolved proteins, we first surveyed for the presence of homologues of OprP and Omp35La using Western blotting. The antisera $\alpha-48$ DP $\mathrm{N}-14$ and $\alpha$-Omp35La detected the same size proteins as OprP and Omp35La in dissolved protein samples collected from quite different oceanic regions, subarctic Pacific Stn A and the Antarctic Ocean surface water. This suggests that the porin homologues of OprP and Omp35La are relatively ubiquitous in the oceans. However, the sizes of reactable proteins were different at subtropical Stn B in the Pacific. Further, in the outer membrane proteins of cultured bacteria, proteins having different sizes were also detected by Western blotting. These data suggest that there are antigenic structures similar to the $\mathrm{N}$-terminus of OprP and the whole molecule of Omp35La present in both dissolved proteins and bacterial outer membrane proteins. As mentioned in the 'Materials and methods', antisera used in this study were relatively specific for the target antigens. An antibody reacts to the specific 'antigenic structure' but not protein per se. Therefore, the detection of the bands with different sizes in Western blotting can be explained by this specific recognition of the antigenic sites. It is not surprising that immunopositive proteins of varying sizes were detected. Similar findings have been observed in the protein toxins of pathogenic bacteria (Suzuki et al. 1994). It has been reported among Gram-negative bacteria that the primary structure of porins varies significantly (Gerbl-Rieger et al. 1991), but amphiphilic $\beta$-strands in the porin barrel are structurally conserved (Jeanteur et al. 1994). Antigenicity of porins are also conserved in different serotypes of Listonella (Vibrio) anguillarum and the genera Vibrio and Photobacterium, although the molecular sizes are different (Suzuki et al. 1996). Thus, the apparent discrepancy of molecular sizes among reactive proteins to the antisera can be explained. The possibility of an artifact due to proteolysis at a specific site(s) within the porin homologues cannot be discounted at this point. This might give small size positive bands after Western blotting. However, in the case of 2 dissolved protein samples and 1 of the bacterial samples, the immunoreactive band of $\alpha-48$ DP N-14 was of larger molecular mass than OprP from Pseudomonas aeruginosa (Fig. 2B; at 500 and $1000 \mathrm{~m}$ ). So proteolysis cannot explain all of the observed size differences.
Under microscopic observations, $\alpha-48$ DP N-14 reacted to the cell surface of intact natural bacteria, indicating that bacteria possessing similar antigenicity to the $\mathrm{N}$-terminus of OprP are widely distributed in the marine environment. Measures of the exact number of FA-stained cells were not very reliable because of relatively low numbers of immunoreactive cells. The simple increase in the volume of filtered seawater, however, did not always improve counting accuracy due to interference by concomitant detrital particles. The FA staining was applied to DVC samples, and DVC counts were approximately of 1 to 2 orders of magnitude lower than total bacterial counts; thus, the actual numbers of the FA-stained bacteria could be higher. Methodological improvements and more extensive field studies remain to be performed to clarify the distribution and dynamics of $\alpha-48$ DP N-14-reactive bacterial cells

The FA staining of $\alpha-48$ DP N-14 and the immunoreactivity to dissolved proteins and bacterial outer membrane proteins after Western blotting in the present study consistently support the hypothesis that bacterial membrane proteins are the source of the $48 \mathrm{kDa}$ protein in the dissolved phase, regardless of location and depth. However, we still cannot rule out the possibility that proteins other than porin have the same $N$-terminal amino acid sequence and molecular mass as OprP. The antiserum $\alpha$-Omp35La also provided evidence that some of the dissolved proteins in seawater are derived from porins of bacteria that belong to the genera Vibrio and Photobacterium. However, the occurrence of source bacteria producing the $48 \mathrm{kDa}$ protein was not confirmed, because the antiserum $\alpha-48$ DP $N-14$ reacted to a few proteins other than the $48 \mathrm{kDa}$ protein. To date, it is not clear whether the FA staining is due to the $48 \mathrm{kDa}$ protein or to other antiserum reactive proteins. Isolation of the $\alpha-48 \mathrm{DP}$ $\mathrm{N}$-14-reactive bacteria from seawater and characterizations of membrane proteins from such bacteria after culture may provide more accurate and detailed information on the source bacteria for dissolved proteins bearing similarity to OprP in the sea. Such an approach may be important in order to answer key questions such as why selective proteins from specific bacteria survive and accumulate and how they are transferred from constituents of living bacteria to the inanimate dissolved protein pool in the sea.

The question why specific porin homologues can survive in seawater is not resolved at present and was not the aim of this paper. However, the recent discovery that Pseudomonas aeruginosa OprD porin has protease activity (Yoshihara et al. 1996) might provide an important clue. That is, some porins show protease activity and some do not. The porins that do not show protease activity might be able to survive, because 
they are not degraded by self-proteolysis. Physical interactions with other molecules such as lipopolysaccharide and/or glycoproteins might provide resistance to porins. Keil \& Kirchman (1993) demonstrated in the laboratory experiment that the turnover time of an enzyme, ribulose 1,5-bisphosphate carbohydlase (RuBPcase), was 2 orders of magnitude shorter than that of RuBPcase that was glycosylated. They suggested that glycosylated proteins were utilized more slowly than proteins that were not, because glycosylation (Maillard-type reactions, amino-carbonyl reactions) has been thought to be responsible for formation of recalcitrant humic substances from biochemical molecules (e.g. Ishiwatari 1992). Such a suggestion, however, may not explain the persistency of porins because no glycosylated porin has been discovered so far.

Acknowledgements. The authors thank I. Koike for his cooperation in seawater sampling. This manuscript was improved by the comments of F. Azam and 3 anonymous reviewers. This work was partly supported by The Sumitomo Foundation (94-104-413) and a Grant-in-Aid from the MESC. Japan.

\section{LITERATURE CITED}

Amon RM, Benner R (1994) Rapid cycling of high-molecularweight dissolved organic matter in the ocean. Nature 369 . $549-552$

Azam F, Fenchel T, Field JG, Gray JS, Meyer-Reil LA, Thingstad $F$ (1983) The ecological role of water-column microbes in the sea. Mar Ecol Prog Ser 10:257-263

Benner RJ, Pakulski JD, MCCarthy MD, Hedges JI, Hathcer PG (1992) Bulk chemical characteristics of dissolved organic matter in the ocean. Science 255:1561-1564

Bohlool BB, Schmidt EL (1968) Nonspecific staining: its control in immunofluorescence examination of soil. Science $162: 1012-1014$

Cauwet G (1978) Organic chemistry of seawater particulates Concepts and developments. Oceanol Acta 1:99-105

Ducklow HW, Carlson CA (1992) Oceanic bacterial production. Adv Microb Ecol 12:113-181

Gerbl-Rieger S, Peters J, Kellermann J, Lottspeich F, Baumeister W (1991) Nucleotide and derived amino acid sequences of the major porin of Comamonas acidovorans and comparison of porin primary structures. J Bacteriol 173:2196-2205

Giovannoni SJ, Britschgi TB, Moyer CL, Field KG (1990) Genetic diversity in Sargasso Sea bacterioplankton Nature 345:60-63

Guo L, Coleman CH Jr, Santschi PH (1994) The distribution of colloidal and dissolved organic carbon in the Gulf of Mexico. Mar Chem 40:1392-1403

Guo L, Santschi PH, Warnken KW (1995) Dynamics of dissoved organic carbon (DOC) in oceanic environment. Limnol Oceanogr 40:1392-1403

Hancock RE, Pool K, Benz R (1982) Outer membrane protein $P$ of Pseudomonas aeruginosa: regulation by phosphate deficiency and formation of small anion-specific channels in lipid bilayer membrane. J Bacteriol 150:730-738
Harlow E, Lane D (1988) Immunoprecipitation. In: Antıbodies, a laboratory manual. Cold Spring Harbor Laboratory, New York, $\mathrm{p} 421-470$

Hedges JI (1987) Organic matter in sea water. Nature 330 . $205-206$

Holt JG, Krieg NR, Sneath PHA, Staley JT, Williams ST (1994) Genus Vibrio. In: Williams RH (ed) Bergey's manual of determinative bacteriology, 9th edn. Williams and Wilkins, Baltimore, p 192-193

Ishiwatari $R$ (1992) Macromolecular material (humic substance) in the water column and sediments. Mar Chem 39: $151-166$

Jeanteur D, Lakey JH, Pattus F (1994) The porin superfamily: diversity and common features. In: Ghuysen JM. Hakenbeck $R$ (eds) Bacterial cell wall. Elsevier, New York, p 363-380

Keil RG, Kirchman DL (1991) Dissolved combined amino acids in marine waters as determined by a vapor-phase hydrolysis method. Mar Chem 33:243-259

Keil RG, Kirchman DL (1993) Dissolved combined amino acids: chemical form and utilization by marine bacteria. Linmol Oceanogr 38:1256-1270

Kogure K, Simidu U, Taga N (1979) A tentative direct microscopic method for counting living marine bacteria. Can J Microbiol 25:415-420

Kragelund L, Nybroe O (1994) Culturability and expression of outer membrane proteins during carbon, nitrogen, or phosphorus starvation of Pseudomonas fluorescens DF57 and Pseudomonas purida DF14. Appl Environ Microbiol 60:2944-2948

Lee C. Wakeham SG (1989) Organic matter in seawater- biogeochemical processes. Chem Oceanogr 9:2-51

Morita J, Suzuki S, Kusuda R (1996) Metalloprotease produced by Listonella anguillarum shows similar activity to plasma activated protein $C$ in rainbow trout coagulation cascade. Fish Pathol 31:9-17

Pomeroy LR (1974) The ocean's food web: a changing paradigm. BioScience 24:499-504

Porter K, Feig YS (1980) The use of DAPI for identifying and counting aquatic microflora. Limnol Oceanogr 25:943-948

Pukulski JD, Benner R (1994) Abundance and distribution of carbohaydrates in the ocean. Limnol Oceanogr 39:930-940

Rashid MA (1985) Geochemistry of marine humic compounds. Springer-Verlag, New York

Schmidt TM, DeLong EF, Pace NR (1991) Analysis of a marine picoplankton community by $16 \mathrm{~S}$ IRNA gene cloning and sequencing. J Bacteriol 173:4371-4378

Simon M, Mathes A, Blanch A, Engelhardt H (1996) Characterization of a porin from the outer membrane of Vibrio anguillarum. J Bacteriol 178:4182-4188

Suzuki S, Kawaguchi M, Mizuno K, Takama K, Yuki N (1994) Immunological properties and ganglioside recognitions by Campylobacter jejuni-enterotoxin and cholera toxin. FEMS Immunol Med Microbiol 8:207-212

Suzuki S, Kuroe K. Kusuda R (1993) Characteristics of ponn-like major outer membrane proteins of Listonella anguillara serotypes J-O-1, -2 and -3. Biochem Mol Biol Int 32:605-613

Suzuki S, Kuroe K, Yasue K, Kusuda R (1996) Antigenicity and N-terminal amino acid sequence of a $35 \mathrm{kDa}$ porinlike protein of Listonella (Vibrio) anguillarum: comparison among different serotypes and other bacterial species. Lett Appl Microbiol 19:276-280

Tanoue E (1995) Detection of dissolved protein molecules in oceanic waters. Mar Chem 51:239-252

Tanoue E, Ishii M, Midorikawa T (1996) Discrete dissolved and particulate proteins in oceanic waters. Limnol Oceanogr 41:1334-1343 
Tanoue E, Nishimura S, Kamo K, Tsugita A (1995) Bacterial membranes: possible source of a major dissolved protein in seawater. Geochim Cosmochim Acta 59:2643-2648

Towbin H, Staehelin T, Gordon J (1979) Electrophoretic transfer of proteins from polyacrylamide gels to nitrocellulose sheets: procedure and some applications. Proc Natl Acad Sci USA 76:4350-4354

Editorial responsibility: Faroog Azam (Contributing Editor), La Jolla, California, USA
Xu HS, Roberts N, Singleton FL, Attwell RW, Grimes DJ, Colwell RR (1982) Survival and viability of nonculturable Escherichia coli and Vibrio cholerae in the estuarine and marine environment. Microb Ecol 8:313-323

Yoshihara E, Gotoh N, Nishino T, Nakae T (1996) Protein D2 porin of the Pseudomonas aeruginosa outer membrane bears the protease activity. FEBS Lett 394:179-182

Submitted: September 11, 1996; Accepted: August 25, 1997 Proofs received from author(s): October 13, 1997 